\title{
PENINGKATAN PENGETAHUAN CARA MENGGOSOK GIGI DENGAN KEJADIAN KARIES GIGI MELALUI UPAYA PENYULUHAN (EDUKASI) KESEHATAN PADA MASYARAKAT DESA JUAI KECAMATAN JUAI KABUPATEN BALANGAN
}

\author{
M. Bahrul Ilmi dan Erwin Ernadi \\ Fakultas Kesehatan Masyarakat, Universitas Islam Kalimantan MAB \\ Email :illmy1202@gmail.com
}

\begin{abstract}
One cause is the high patient dental caries is the pattern of brushing your teeth is still anything wrong, lack of awareness in the patient undergoing treatment and healing process includes went to health services for prevention. The purpose of this service activities is to increase public knowledge about the prevention and treatment of dental caries disease. The method is performed in service activities is a lecture / extension, namely the provision of information (education) about brushing teeth and dental caries. Targets in community service activities are 15-60 years of age because this age group is the age group most vulnerable to suffer from dental caries so that they can explain to their children or relatives. These service activities will be conducted from November 2016 to January 2017. Hopefully with this service activities, more and more people know about the information how to brush their teeth so they can reduce or avoid the disease dental caries.
\end{abstract}

Keywords:Brushing teeth, dental caries, knowledge

\section{PENDAHULUAN}

Prevalensi penduduk yang bermasalah gigi dan mulut menurut kabupaten/kota di Provinsi Kalimantan Selatan berdasarkan Riskesdas tahun 2007, penduduk yang bermasalah pada gigi dan mulut memiliki prevalensi tertinggi di daerah Barito Kuala 39,5\%, diikuti dengan Banjarmasin 38,2\% dan Balangan sebesar 35,2\%. Jika dibandingkan tingkat keparahan gigi (indeks DMF-T), Nampak ada 5 kabupaten dengan tingkat keparahan tertinggi di antaranya Hulu Sungai Utara, Balangan, Hulu Sungai Tengah,
Banjar, dan Hulu Sungai Selatan.

$$
\text { Balangan adalah kabupaten }
$$
dengan tingkat keparahan DMF-T tertinggi yang kedua setelah Hulu Sungai Utara, prevalensi DMF-T di Balangan adalah sebesar $8,59 \%$ gigi meliputi $6,77 \%$ gigi yang dicabut atau indikasi pencabutan, $1,77 \%$ karena gigi karies/berlubang, dan 0,09\% gigi yang ditumpat.

Secara geografis, Wilayah Kecamatan Juai seluas $386,88 \mathrm{~km}^{2}$ atau $21 \%$ dari luas wilayah Balangan (Nomor 2 terbesar setelah kecamatan 
Halong). Kecamatan Juai terletak pada lingkup koordinat 2001'37" sampai dengan 2035'58" Lintang Selatan dan 114050'24" sampai dengan 115050'24" Bujur Timur.

Kecamatan Juai terdiri dari 21 desa. Daerah yang paling luas adalah desa Lalayau mencapai $8,45 \%$ atau $32,70 \mathrm{~km}^{2}$, dan desa yang mempunyai luas terkecil yaitu desa Panimbaan luasnya hanya $2,64 \%$ atau $10,21 \mathrm{~km}^{2}$. Untuk desa Juai sendiri termasuk urutan ke 4 dari luas wilayah terbesar di kecamatan Juai yaitu 25,21 $\mathrm{km}^{2}$ $(6,52 \%)$.

\section{KHALAYAK SASARAN}

Sasaran dalam kegiatan pengabdian ini adalah masyarakat desa Juai, dimana daerah tersebut adalah wilayah pinggiran sungai yang merupakan salah satu factor risiko terjadinya karies gigi. Tingkat pendidikan masyarakat desa Juai yang masih rendah mengakibatkan pengetahuan tentang karies gigi juga masih rendah. Pengetahuan menjadi sangat penting dalam menentukan sikap dan perilaku masyarakat dalam melakukan tindakan pencegahan dan pengobatan karies gigi.

\section{METODE}

Peningkatan pengetahuan masyarakat mengenai karies gigi dilakukan dengan cara pemberian informasi (edukasi) berupa penyuluhan kesehatan mengenai karies gigi seperti penyebab, tanda dan gejala karies gigi, serta upaya pencegahan dan pengobatannya. Langkah-langkah dalam pelaksanaananya antara lain:

1. Tahap persiapan

a. Penyusunan pre planning.

b. Langkah pertama adalah membuat kontrak waktu dan tempat penyuluhan dengan masyarakat.

c. Persiapan media berupa leaflet dan materi penyuluhan yang memberikan informasi mengenai karies gigi.

d. Persiapan alat peraga dan souvenir untuk demonstrasi cara menggosok gigi.

2. Tahap pelaksanaan

a. Kegiatan penyuluhan ini dilakukan dengan cara mengumpulkan masyarakat dengan koordinasi pemerintah setempat. Masyarakat yang diundang adalah kelompok usia dewasa karena usia ini lebih rentan 
untuk terkena penyakit Karies

Gigi.

b. Kegiatan penyuluhan diawali dengan sambutan tokoh masyarakat setempat.

c. Penyuluhan diawali dengan pemberian informasi, menggunakan materi yang sudah disiapkan dilanjutkan dengan tanya jawab atau diskusi dengan masyarakat.

d. Demonstrasi lapangan dengan memperagakan tatacara menggosok gigi yang benar.

\section{HASIL DAN PEMBAHASAN}

Susunan dari pelaksanaan pengabdian antara lain:

Jenis Kegiatan : Penyuluhan

Tempat : Rumah salah

satu masyarakat di desa Juai

Waktu : Pukul 13.45,

Sabtu tanggal 17 Desember 2016

Peserta : Masyarakat desa

Juai

Tabel Uraian Kegiatan Penyuluhan

\begin{tabular}{|c|c|c|}
\hline $\begin{array}{c}\text { Waktu } \\
(17 \\
\text { Desember } \\
2016)\end{array}$ & $\begin{array}{c}\text { Jenis } \\
\text { Kegiatan }\end{array}$ & $\begin{array}{c}\text { Penanggung } \\
\text { Jawab }\end{array}$ \\
\hline $\begin{array}{c}\text { Pkl. 13.30- } \\
13.45\end{array}$ & Persiapan & Tim Pelaksana \\
\hline $\begin{array}{l}\text { Pkl. 13.45- } \\
14.00\end{array}$ & Pembukaan & $\begin{array}{l}\text { Tokoh } \\
\text { Masyarakat } \\
\text { (H. M. } \\
\text { Thamrin) }\end{array}$ \\
\hline
\end{tabular}

\begin{tabular}{|c|c|c|}
\hline $\begin{array}{c}\text { Pkl. 14.00- } \\
14.15\end{array}$ & $\begin{array}{l}\text { Pemberian } \\
\text { Materi } \\
\text { KEJADIAN } \\
\text { KARIES } \\
\text { GIGI }\end{array}$ & $\begin{array}{l}\text { Pemateri } \\
\text { (M. Bahrul } \\
\text { Ilmi, SKM,. } \\
\text { M.Kes) }\end{array}$ \\
\hline $\begin{array}{c}\text { Pkl. 14.15- } \\
14.45\end{array}$ & $\begin{array}{l}\text { Pemberian } \\
\text { Materi } \\
\text { CARA } \\
\text { MENGGOS } \\
\text { OK GIGI }\end{array}$ & $\begin{array}{l}\text { Pemateri } \\
\text { (Erwin Ernadi, } \\
\text { SKM., M.Kes) }\end{array}$ \\
\hline $\begin{array}{c}\text { Pkl. 14.45- } \\
15.15\end{array}$ & $\begin{array}{l}\text { Diskusi } \\
\text { Tanya jawab }\end{array}$ & Tim Pelaksana \\
\hline Pkl. 15.15 & Penutup & Tim Pelaksana \\
\hline
\end{tabular}

Berdasarkan hasil penyuluhan, diskusi dan tanya jawab yang dilakukan kepada masyarakat yang berhadir saat kegiatan, didapatkan hasil pembahasan antara lain:

1. Kesehatan gigi masyarakat desa Juai sangatlah penting mengenai karies gigi, apalagi tidak dirawat tentunya meyebabkan rasa sakit, gangguan pengunyahan dan mengganggu kesehatan tubuh lainnya.

2. Faktor-faktor yang mempengaruhi karies gigi :

a. Gizi. Dalam hal kekurangan gizi, gigi-gigi mudah diserang karies. Jadi gizi merupakan salah satu faktor yang penting dalam etiologi karies (Abraham, M. Rudolph, 2006). Masyarakat desa Juai yang masih banyak belum mengerti 
mengenai jenis asupan

makanan begizi.

b. Geografis. Desa Juai yang sebagian besar masyarakatnya berada di pinggiran sungai, air sungai masih dipergunakan untuk MCK.

c. Kebersihan gigi dan mulut yang kurang terawat, mengakibatkan presentasi karies lebih tinggi.

3. Masyarakat desa Juai senang makan-makanan manis, makanan jenis ini mudah terselip di dalam permukaan gigi yang nantinya oleh kuman akan merubah menjadi asam yang menyebabkan karies gigi.

\section{FOTO KEGIATAN}

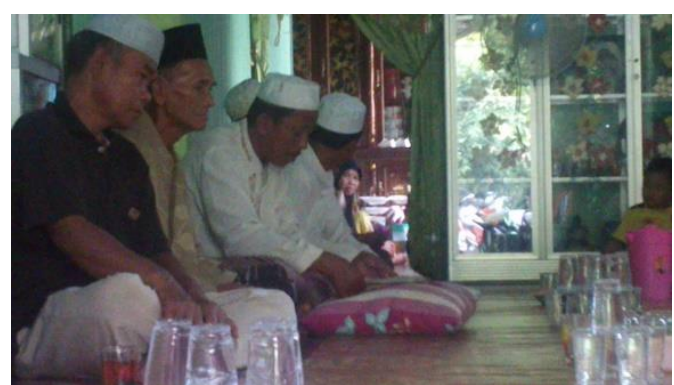

Pembukaan kegiatan penyuluhan

sekaligus sambutan dari tokoh masyarakat setempat (H. M. Thamrin)

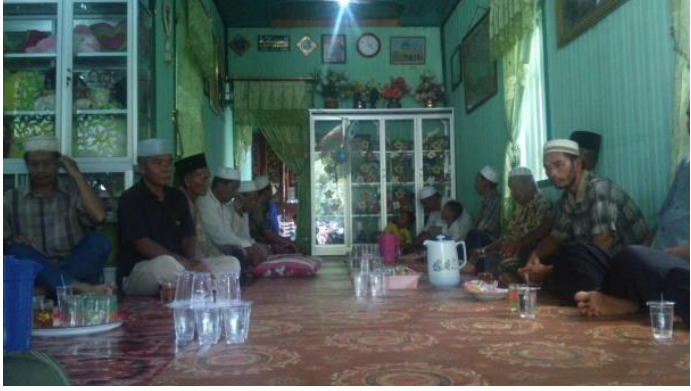

Diskusi dan Tanya jawab mengenai materi "Kejadian karies \& Cara

Menggosok Gigi"

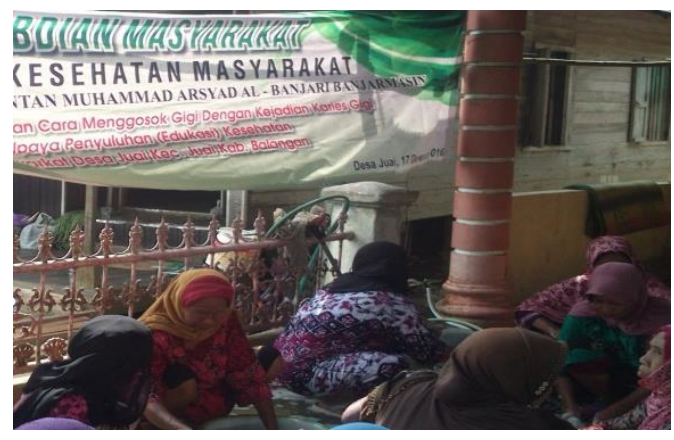

Praktek langsung cara menggosok gigi yang benar, pengarahan di bantu oleh

Rahmi Safitri (tenaga pembantu \& administrasi)

\section{KESIMPULAN}

Masih banyak masyarakat desa Juai yang giginya kurang terawat sehingga menyebabkan rasa sakit, gangguan pengunyahan dan kesehatan tubuh lainnya. Faktor karies gigi yang terlihat seperti kekurangan gizi (asupan makanan), Desa Juai yang sebagian besar masyarakatnya berada di pinggiran sungai, air sungai masih 
dipergunakan untuk MCK serta senang makan-makanan manis tapi masih kurang kesadaran dalam membersihkan gigi setelah memakannya.

Semoga hasil pengabdian ini mampu menambah pengetahuan dan adanya perubahan sikap yang lebih baik, bahan masukan kepada masyarakat dalam peningkatan kesehatan gigi dan mulut khususnya mengenai karies gigi dilihat dari penyebab, tanda, gejala, cara pencegahan dan pengobatan sehingga dapat berperilaku sehat dalam memelihara kesehatan gigi dan mulut. Pengabdian selanjutnya semoga dapat mengkaji lebih mendalam mengenai kejadian karies di desa Juai sehingga dapat lebih mengoptimalkan masyarakat dalam menjaga serta merawat kesehatan gigi dan mulut.

\section{DAFTAR PUSTAKA}

Abraham

M.Rudolph,2006. Mengenaikariesgigi :Jakarta

Badan Pusat Statistik Kabupaten Balangan, 2012. Kecamatan Juai Dalam Angka 2012. Katalog BPS 1102001.63.11.010 : Balangan

Biddulp, Jhonn. 1999. KesehatanAnakYogyakarta : UGM
DepartemenKesehatan RI, 2009. Indonesia Sahat.Jakarta :DepartemenKesehatan.

Depkes, 1996.PetunjukPemeliharaanKes ehatan Gigi danMulutKeluarga: Jakarta

Ginanjar, R. 2010. Cara Menyikat Gigi yang Benar. (online). (www.pikiranrakyat.comdiakses 16 April 2016).

IrchamMachfoedzdanAsmarYettiZein.2 008. MenjagaKesehatan Gigi danMulutAnakanakdanIbuHamil.Yogyakarta :Tramaya

Notoatmodjo, Soekidjo. 2010. MetodologiPenelitianKesehatan. Jakarta :RinekaCipta.

Rahardjo, Anton. 2010. KariesDominasiMasalah Gigi. (online).

(http://www.jurnalnet.com/konte n.php?nama=BeritaUtama\&topi $\mathrm{k}=7 \& \mathrm{id}=663$ diaksestanggal 29 Oktober 2016).

Srigupta, Aziz Ahmad. 2004. Perawatan Gigi danMulut.Jakarta :PrestasiPustaka.

Setiadi. 2007. KonsepPenulisanRisetKeperawa tan. Yogyakarta: Grahallmu.

TimPenyusun.Risetkesehatandasarnasio nal2007.Jakarta:

BadanPenelitiandanPengembang anKesehatan.

Wahab, ASamik, 1999. IlmuKesehatanAnak Nelson. Vol. 1. Jakarta: EGC. 